\title{
Distribution and partitioning of nitrogen and phosphorus in a fringing reef lagoon of Ishigaki Island, northwestern Pacific
}

\author{
Toshihiro Miyajima ${ }^{1, *}$, Hiroshi Hata ${ }^{2,3}$, Yu Umezawa ${ }^{1,4}{ }^{,}$, Hajime Kayanne ${ }^{2}$, Isao Koike ${ }^{1}$ \\ ${ }^{1}$ Ocean Research Institute, The University of Tokyo, Minamidai 1-15-1, Nakano, Tokyo 164-8639, Japan \\ ${ }^{2}$ Department of Earth and Planetary Science, The University of Tokyo, Hongo 3-8-1, Bunkyo-ku, Tokyo 113-0033, Japan \\ ${ }^{3}$ Present address: Hazama Technical Research Institute, Karima 515-1, Tsukuba 305-0822, Japan \\ ${ }^{4}$ Present address: Research Institute for Humanity and Nature, Motoyama 457-7, Kamigamo, Kyoto 603-8047, Japan
}

\begin{abstract}
Concentration of dissolved and particulate carbon (C), nitrogen (N), and phosphorus (P) were measured daily and seasonally in the water column of a coral reef lagoon at Ishigaki Island. Concentrations of dissolved inorganic $\mathrm{N}$ and $\mathrm{P}$ (DIN, DIP), dissolved organic $\mathrm{C}$ and $\mathrm{N}$ (DOC, DON), particulate organic $\mathrm{C}$, and particulate $\mathrm{N}$ and $\mathrm{P}$ (POC, $\mathrm{PN}, \mathrm{PP}$ ) were usually higher in the lagoon than at offshore stations, while dissolved organic $\mathrm{P}$ (DOP) was higher at the offshore stations than in the lagoon. Concentration ratios of DIN:DIP and PN:PP were near 16:1 in winter and $>20: 1$ in summer. DON:DOP was always $\geq 30$. Total P (DIP + DOP + PP) was fairly constant around $0.177 \pm 0.025 \mu \mathrm{mol}$ $\mathrm{l}^{-1}$ (mean $\left.\pm \mathrm{SD}\right)$, suggesting conservative behavior of water-column $\mathrm{P}$ around this reef. DIP and PP seemed to be produced at the expense of DOP, and PP rather than DIP increased when gross primary production (GPP) was high. In contrast, total N (DIN + DON + PN) showed large spatial and seasonal variation from 4.3 to $12.4 \mu \mathrm{mol} \mathrm{l}^{-1}$. DON and PN increased when GPP and DIN:DIP were high, which suggests that export production of organic $\mathrm{N}$ by the lagoon biota was enhanced by primary production and the availability of $\mathrm{N}$ relative to $\mathrm{P}$. Estimation of $\mathrm{C}, \mathrm{N}$, and $\mathrm{P}$ exchange fluxes between the lagoon and the outer ocean using a simple hydrodynamic model showed that the lagoon ecosystem released $N$ (especially DIN) but not P to the surrounding ocean. Oceanic DOP could be the major source for the $\mathrm{P}$ budget of the lagoon. While the lagoon was a net source of organic $\mathrm{C}$ to the outer ocean, the net export was only a minor fraction $(<5 \%)$ of gross exchange of organic $C$ between these 2 ecosystems.
\end{abstract}

KEY WORDS: N:P stoichiometry $\cdot$ Coral reef biogeochemistry $\cdot$ Dissolved organic matter $\cdot$ Seasonal variation · Gross primary production · East China Sea

\section{INTRODUCTION}

Coral reef ecosystems receive nitrogen $(\mathrm{N})$ and phosphorus (P) primarily as dissolved inorganic forms from oceanic water flowing into them (D'Elia 1988). Dominant ocean currents, drift currents, and/or tidal water exchange provide the reef ecosystem with a large lateral flux of seawater, which, however, usually contains extremely low concentrations of dissolved inorganic nutrients. Since reef biota has developed an ability to extract nutrients even at low concentrations, the large advective fluxes of offshore seawater potentially suffice for all nutrient requirements of the reef biota (Charpy 2001). However, the actual rates by which the reef biota can extract dissolved substances from flowing seawater are physically constrained, and the maximal nutrient uptake rates that are allowed by the hydrodynamic constraints are often smaller than the nutrient requirements, especially for $\mathrm{N}$, estimated from measured net primary production of organic carbon (C) and typical C:N:P ratios (e.g. 550:30:1; Atkinson \& Smith 1983) of the reef biota (Atkinson \& Falter 2003). 
A possible explanation for this imbalance between the requirements and the maximal uptake rates for $\mathrm{N}$ or $\mathrm{P}$ is continual production and release of low-quality (i.e. high $\mathrm{C}: \mathrm{N}$ or $\mathrm{C}: \mathrm{P}$ ) dissolved and/or particulate organic matter by the biota, retaining $\mathrm{N}$ and $\mathrm{P}$ within the biomass (Atkinson \& Falter 2003, Tanaka et al. 2006). As an alternative explanation, additional $\mathrm{N}$ and $\mathrm{P}$ sources other than the oceanic dissolved nutrients have been postulated (D'Elia \& Wiebe 1990). They include: (1) offshore nutrient sources such as capture of particulate organic matter by particle feeders (Tomascik \& Sander 1985, Hamner et al. 1988) and tide-induced upwelling of nutrient-rich deep water (Wolanski et al. 1988, Leichter et al. 1996); (2) atmospheric sources such as dinitrogen fixation by cyanobacteria (Wiebe et al. 1975, Wilkinson et al. 1984, Larkum et al. 1988); and (3) landor bottom-derived nutrient sources such as groundwater discharge (D'Elia et al. 1981), resuspended sediment flux (Rosenfield et al. 1999, Anthony 2000), and endo-upwelling (Rougerie et al. 1992). Concentrations and composition of dissolved inorganic nutrients in the surrounding ocean as well as the availability of additional nutrient sources can be considerably different from reef to reef depending on oceanographic settings of the reefs, such as latitude, dominant ocean currents, water turnover rate, and distance from the mainland.

Many coral reefs occur in tropical and subtropical shallow waters where planktonic primary productivity is most likely limited by the availability of $\mathrm{N}$ rather than P (Moore et al. 2002). In fact, the majority of the previous studies of nutrient dynamics have been conducted in reef sites where dissolved inorganic nitrogen to phosphorus (DIN:DIP) atomic ratios in seawater were typically $<10$, much smaller than the typical biomass N:P ratio of 30 for reef biota (Andrews \& Müller 1983, Entsch et al. 1983, Charpy-Roubaud et al. 1990, Rasheed et al. 2002; see also Table 10.2 in D'Elia 1988 for a review of many older studies). However, this is not always the case in coastal areas that receive significant nitrogen input from the land. For example, the East China Sea (ECS), to which a large amount of freshwater is continually supplied by the Changjiang and other large rivers, is often under P-limited conditions due to substantial terrestrial $\mathrm{N}$ input (Wong et al. 1998, Hung et al. 2003). Such a difference in N:P stoichiometry potentially exerts a considerable influence on primary productivity and the nutrient biogeochemistry of the reef ecosystem, including production and remineralization of organic $\mathrm{N}$ and $\mathrm{P}$ species. Influence of the reef ecosystem on the water chemistry of the surrounding ocean may also be contrasting depending on $\mathrm{N}: \mathrm{P}$. It may be hypothesized that high DIN:DIP ratios in the oceanic water input to a reef ecosystem should result in high organic-N:organic-P ratios in the export water from the reef to the ocean.
Latitude is another important external condition that affects reef metabolism. In contrast to other reef systems, high-latitude (subtropical) coral reefs are generally characterized by high abundance of macroalgal populations, large flux of detrital organic carbon due to algal biomass production and erosion (Crossland et al. 1984), and large seasonal variation in biological production (Kayanne et al. 2005a). Higher detrital flux may stimulate heterotrophic production within the back reef area and modify the pathways of nutrient recycling in the ecosystems. Seasonal cycling of productivity implies that reef metabolism may not be in a steady state. The overall budgets of $\mathrm{C}, \mathrm{N}$, and $\mathrm{P}$ of such a reef ecosystem may not be strictly coupled with each other within the time span of days, weeks, and even months. Thus, exact mechanisms that regulate the nutrient balances in individual coral reefs are still controversial and require further investigation, especially with appropriate focus on seasonal cycles.

In this study, distributions of DIN, DIP, dissolved organic carbon (DOC), nitrogen (DON), and phosphorus (DOP), particulate organic carbon (POC), and particulate nitrogen (PN) and phosphorus (PP) were investigated in and outside a high-latitude $\left(24.3^{\circ} \mathrm{N}\right)$ fringing coral reef at Ishigaki Island, Japan, on the border between the ECS and the subtropical northwestern Pacific Ocean. Clear seasonal changes in biological productivity have been observed in this reef (Kayanne et al. 2005a). Although the ECS water does not directly affect this reef because of the Kuroshio Current that usually flows across between the island and the ECS, the oceanic water around this reef is often relatively rich in DIN. In addition, groundwater that contains a high concentration of $\mathrm{NO}_{3}^{-}$of anthropogenic origin flows into the lagoon of this reef, and the loaded $\mathrm{NO}_{3}{ }^{-}$ is actually utilized by primary producers inhabiting the area along the shoreline (Umezawa et al. 2002a). This extra $\mathrm{N}$ input may further render this reef rich in $\mathrm{N}$ relative to $\mathrm{P}$. In this paper, temporal changes in the lagoon and spatial differences between inside and outside the lagoon in concentration and partitioning of $\mathrm{N}$ and $\mathrm{P}$ into dissolved inorganic, dissolved organic, and particulate phases are described with an emphasis on the effects of seasonal variability of productivity and N:P stoichiometry. Exchange fluxes of N, P, and organic C between this reef ecosystem and the outer ocean were estimated using a simple hydrodynamic model of the lagoon to depict contrasting behavior among these elements.

\section{MATERIALS AND METHODS}

Site description. Shiraho reef $\left(24^{\circ} 21-22^{\prime} \mathrm{N}, 124^{\circ} 15^{\prime} \mathrm{E}\right)$ is a fringing coral reef to the east of Ishigaki Island, 
NW Pacific (Fig. 1). The reef crest is developed roughly parallel to the shoreline at a distance of ca. $850 \mathrm{~m}$. The depth of the lagoon, surrounded by the crest and the island, is mostly $\leq 3 \mathrm{~m}$ of the mean sea level (MSL). The hydrodynamics in the reef flat are strongly constrained by the tidal cycle, as follows (Miyajima et al. 2007). The lagoon is almost isolated from the outer ocean by the emerged crest during the low tide period $(1-6 \mathrm{~h}$, depending on the tide range). During this stagnant (slack-water) period, the lagoon water usually flows from north to south at a few $\mathrm{cm} \mathrm{s}^{-1}$, although wind velocity influences the flow regime to some extent. In contrast, the lagoon can exchange seawater with the outer ocean over the reef crest during the high tide
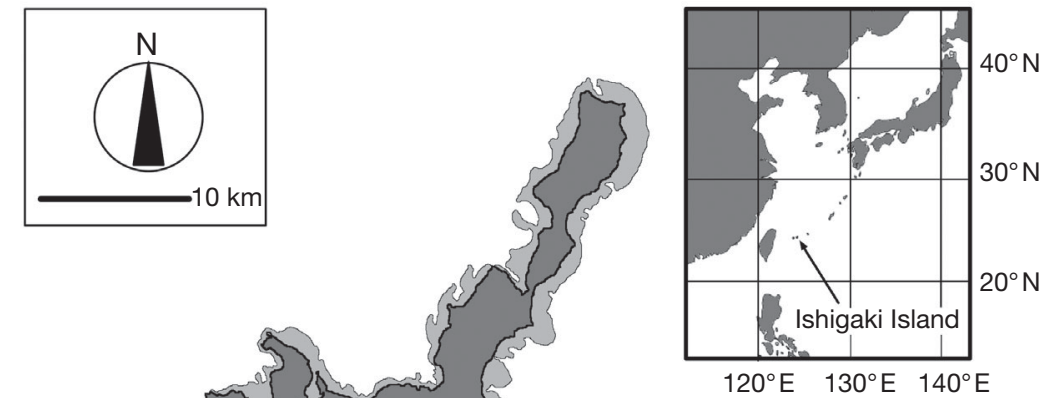

(flooding) period, with water current velocity in the lagoon being 10 to $50 \mathrm{~cm} \mathrm{~s}^{-1}$. The lagoon water is almost completely replaced with offshore water during a single flooding period.

Sessile macrophyte vegetation in the lagoon shows roughly belt-like zonation. Patchy seagrass beds occur in the nearshore part of the lagoon, up to $350 \mathrm{~m}$ from the shoreline of the island. Large patches of hermatypic corals abundantly occur in the zone between $500 \mathrm{~m}$ and $700 \mathrm{~m}$ from the shoreline. A large gap zone of macrophytes, which is covered with pristine carbonate sand, exists between the seagrass beds and the coral belt. Exposed reef rocks are found in this sandy area as well as in seagrass beds, on which small coral colonies and seasonal macroalgal populations develop. The bottom of the area $>600 \mathrm{~m}$ off the shoreline is mostly covered with reef rocks, on which brown algae such as Sargassum and Padina grow from spring through autumn. During the low tide periods, groundwater containing 50 to $300 \mu \mathrm{M} \mathrm{NO}_{3}{ }^{-}$seeps out along the shoreline (Umezawa et al. 2002b). Groundwater is rapidly mixed with seawater, and traces of groundwater such as salinity and temperature anomalies diminish within $50 \mathrm{~m}$ of the shoreline (Umezawa 1998). However, stable nitrogen isotopic signatures $\left(\delta^{15} \mathrm{~N}\right)$ of some macroalgae are elevated within at least $300 \mathrm{~m}$ of the shoreline, which indicates that they use groundwater-derived $\mathrm{N}$ directly or indirectly to a detectable extent, because no other reef process generates such a pattern of $\delta^{15} \mathrm{~N}$ (Umezawa et al. 2002a).

Water sampling procedures. The survey was conducted 5 times (i.e. September and December 1998, March, June, and September 1999). Water temperature during the study periods ranged between 22.4 and $32.7^{\circ} \mathrm{C}$. Prevailing wind direction was southerly

in June and northerly in the other survey months. For each of the 5 periods, extensive monitoring for 3 to $4 \mathrm{~d}$ at spring tide was carried out. Usually, we had low tides at around noon and midnight, and high tides in the morning and evening; that is, there were 2 stagnant periods (daytime and night) and 2 flooding periods per day. Water samples and physical data were obtained simultaneously on a boat moored at the center of the lagoon (ca. $500 \mathrm{~m}$ east of the shoreline; water depth, 160 to $320 \mathrm{~cm}$; Fig. 1). Many colonies of branched corals such as Porites spp. and Acropora spp. grew around this site. Although the bottom area just below the sampling point was mostly covered with carbonate sand, the nearest colonies of hermatypic corals occurred within $10 \mathrm{~m}$ of the boat.

Water samples for chemical analysis were collected using a submergible pump from $80 \mathrm{~cm}$ below the water surface. The pump worked continuously during the whole study period except short intermittences for maintenance. Samples for nutrient analyses $(10 \mathrm{ml}$ in duplicates) were collected in screw-capped acrylic tubes at $30 \mathrm{~min}$ and $60 \mathrm{~min}$ intervals for the stagnant and flooding periods, respectively. Samples for total dissolved $\mathrm{N}$ (TDN) and $\mathrm{P}$ (TDP), POC, PN, PP, and chlorophyll a (chl a) analyses (total ca. 10 l) were collected into polypropylene bottles at $60 \mathrm{~min}$ and $120 \mathrm{~min}$ intervals for the stagnant and flooding periods, respectively. Samples for DOC were collected at the same intervals as TDN and TDP, and immediately filtered on board through Whatman GF/F filters (Ø $25 \mathrm{~mm}$ ) into screw-capped glass vials (30 ml). Water samples were temporarily stored on ice and transported to the laboratory at the beginning and end of each flooding period. Nutrient samples were frozen at $-20^{\circ} \mathrm{C}$ for later analysis. Samples for POC + PN (5 to 
$10 \mathrm{l})$, PP $(200 \mathrm{ml})$, and $\mathrm{chl}$ a $(200 \mathrm{ml})$ were separately filtered through Whatman GF/F filters $(\varnothing 25 \mathrm{~mm})$ within $6 \mathrm{~h}$ of sampling. The filters for POC + PON and PP were immediately frozen, while the filters for chl $a$ were soaked in $N, N$-dimethylformamide $(100 \%, 6 \mathrm{ml})$ in polypropylene tubes and stored at $-20^{\circ} \mathrm{C}$ in the dark. A portion (ca. $50 \mathrm{ml}$ ) of the filtrates was stored in polypropylene bottles frozen at $-20^{\circ} \mathrm{C}$ for later analysis of TDN and TDP. In addition, offshore surface water ( 0.5 to $10 \mathrm{~km}$ off the reef crest along the line shown in Fig. 1, at 4 to 11 sites) was collected by a Van Dorn sampler in each season, and similarly treated to the lagoon water samples.

For every sampling, new acrylic tubes, new autopipetter tips, acid-washed (1 $\mathrm{N} \mathrm{HCl}$, overnight) glass and polypropylene bottles, and precombusted $\left(550^{\circ} \mathrm{C}\right.$, $1 \mathrm{~h})$ DOC vials were always employed and vigorously washed at least twice with the same seawater as samples just before sampling. Acid-washed glassware, new and clean pipetter tips, precombusted glassfiber filters, and clean plastic gloves were always employed for filtration and pretreatments for analyses.

Water temperature (TW), $\mathrm{pH}$, and salinity were continuously monitored during the observation periods with a sensor probe (H20, HYDROLAB). Underwater (sea floor) photosynthetically available radiation (PAR) was monitored continuously using a photon quantum sensor (LI-192SA, Li-Cor). The start and end times of the stagnant periods were determined by analyzing temporal change of water depth monitored by acoustic Doppler current profilers (Argonaut-XR, SonTek). Mean TW, $\mathrm{pH}$, and salinity during the survey periods and mean PAR during the daytime stagnant periods in each of the survey periods are reported in Table 1.

Chemical and statistical analyses. Concentrations of dissolved nutrients $\left(\mathrm{NO}_{3}^{-}, \mathrm{NO}_{2}^{-}, \mathrm{NH}_{4}{ }^{+}, \mathrm{PO}_{4}{ }^{3-}\right)$ were determined by an AutoAnalyzer AACS-II (BRAN+ LUEBBE). The acrylic tubes that contained seawater samples were directly set in the autosampler in a clean hood. Standard protocols provided by BRAN+LUEBBE Japan were used. With a $50 \mathrm{~mm}$ light path, the analyt-

Table 1. Water temperature (TW), pH, salinity (all average for the whole survey period), and light intensity (photosynthetically available radiation, PAR; averaged for the daytime stagnant periods) in the lagoon during the 5 survey periods

\begin{tabular}{|lcccc|}
\hline $\begin{array}{l}\text { Survey } \\
\text { period }\end{array}$ & $\begin{array}{c}\text { TW } \\
\left({ }^{\circ} \mathrm{C}\right)\end{array}$ & pH & $\begin{array}{c}\text { Salinity } \\
(\mathrm{psu})\end{array}$ & $\begin{array}{c}\mathrm{PAR} \\
\left(\mu \mathrm{mol} \mathrm{m} \mathrm{m}^{-2} \mathrm{~s}^{-1}\right)\end{array}$ \\
\hline 21-24 Sep 1998 & 28.9 & 8.2 & 34.7 & 700 \\
03-05 Dec 1998 & 25.5 & 8.4 & 34.4 & 335 \\
18-21 Mar 1999 & 25.2 & 8.3 & 34.5 & 579 \\
29 Jun-01 July 1999 & 30.0 & 8.4 & 34.3 & 987 \\
25-28 Sep 1999 & 28.2 & 8.5 & 34.2 & 671 \\
\hline
\end{tabular}

ical quantitation limit was below $0.01 \mu \mathrm{M}$ and the reproducibility was within $\pm 0.003 \mu \mathrm{M}$. TDN and TDP in seawater were determined by the wet oxidation method using $\mathrm{K}_{2} \mathrm{~S}_{2} \mathrm{O}_{8}$ (Grasshoff et al. 1999). Concentrations of $\mathrm{NO}_{2}{ }^{-}+\mathrm{NO}_{3}{ }^{-}$and $\mathrm{PO}_{4}{ }^{3-}$ resulting from the wet oxidation were determined using AACS-II. Concentrations of DON and DOP were obtained by subtracting DIN $\left(\mathrm{NO}_{3}{ }^{-}+\mathrm{NO}_{2}^{-}+\mathrm{NH}_{4}{ }^{+}\right)$and DIP $\left(\mathrm{PO}_{4}{ }^{3-}\right)$ from TDN and TDP, respectively.

Concentrations of POC and PN were determined by an elemental analyzer, and DOC was determined by the high-temperature catalytic oxidation method (Hata et al. 2002). PP was determined for $25 \mathrm{~mm}$ filter samples by the dry oxidation method (Solórzano \& Sharp 1980) using $\mathrm{Mg}\left(\mathrm{NO}_{3}\right)_{2}$ instead of $\mathrm{MgSO}_{4}$ (Cembella et al. 1986). Chl a was determined by the fluorometric method (Turner Design 10AU) for $N, N$-dimethylformamide in which a $25 \mathrm{~mm}$ filter sample had been soaked (Suzuki \& Ishimaru 1990).

The software package StatView v.5 (SAS Institute) was employed for analysis of variance (ANOVA) and regression analyses, and pro Fit v.6 (QuantumSoft) was used for curve-fitting and plotting. Statistical differences in concentrations and stoichiometries between lagoon and offshore waters, between stagnant and flooding periods, and between daytime and nighttime stagnant periods were evaluated individually by a 2-way ANOVA with seasonal variation as another independent variable. When seasonal variation proved significant, then the significance of differences between individual study periods was evaluated by the Bonferroni-Dunn post-hoc analysis.

\section{RESULTS}

DIN (as well as its components $\mathrm{NO}_{3}{ }^{-}, \mathrm{NO}_{2}{ }^{-}$, and $\mathrm{NH}_{4}{ }^{+}$) was always much higher in the lagoon than in the offshore water $(p<0.0001)$ (Fig. 2a). Seasonal variation in DIN in the lagoon was largely ascribed to seasonal variation in $\mathrm{NO}_{3}{ }^{-}$, which was significantly higher in the order of June $99>$ March $99>$ September $99>$ December $98 \sim$ September $98\left(\mathrm{p} \leq\right.$ 0.0025). $\mathrm{NO}_{2}{ }^{-}$ showed a similar seasonal trend to $\mathrm{NO}_{3}{ }^{-}$, but was one order of magnitude lower (usually $<0.1 \mu \mathrm{M}$ in the lagoon, $<0.02 \mu \mathrm{M}$ in the offshore water) than $\mathrm{NO}_{3}{ }^{-}$ (usually 0.2 to $1.5 \mu \mathrm{M}$ in the lagoon, $<0.2 \mu \mathrm{M}$ in the offshore water). $\mathrm{NH}_{4}{ }^{+}$(usually 0.2 to $1.0 \mu \mathrm{M}$ in the lagoon, $<0.2 \mu \mathrm{M}$ in the offshore water) was in a similar concentration range to $\mathrm{NO}_{3}{ }^{-}$, but showed different and smaller seasonal variation: September $98 \sim$ September $99>$ June $99>$ December $98 \sim$ March 99 ( p < 0.05). DIP was also higher in the lagoon than in the offshore water $(p<0.0001)$ (Fig. 2b), though the difference was not as pronounced as DIN. In the lagoon, DIP was 

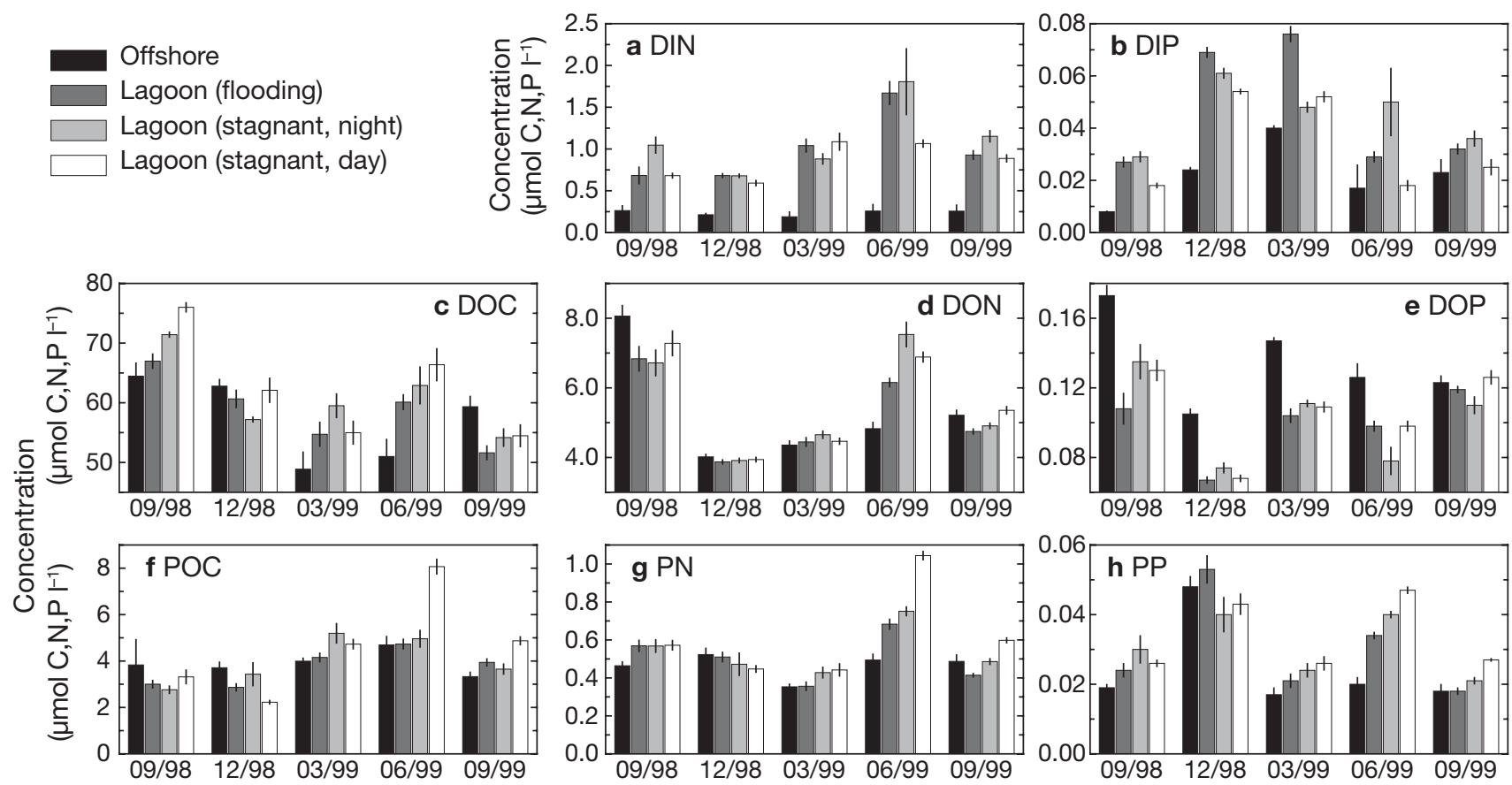

Fig. 2. Mean concentrations ( $\mu \mathrm{mol} \mathrm{l}^{-1}$ ) of (a) DIN, (b) DIP, (c) DOC, (d) DON, (e) DOP, (f) POC, (g) PN, and (h) PP in the lagoon water of Shiraho reef and the offshore water during 5 study periods (September and December 1998, March, June, September 1999). Error bar indicates \pm SE. Values for the lagoon are presented separately for daytime stagnant periods, nighttime stagnant periods, and flooding periods. Date = mm/yy. DIN: dissolved inorganic nitrogen, DIP: dissolved inorganic phosphorus, DOC: dissolved organic carbon, DON: dissolved organic nitrogen, DOP: dissolved organic phosphorus, POC: particulate organic carbon, PN: particulate nitrogen, PP: particulate phosphorus

higher in winter (December 98, March 99) than in summer (September 98, June 99, September 99; p < 0.0001). DIN and DIP were higher in the night stagnant periods than in the daytime stagnant periods except in March 99. The mean DIN:DIP ratio in the offshore water was higher in September 98 and June 99 (33.4 and 27.9) than in the other periods (4.2 to 9.0; Table 2). In the lagoon, mean DIN:DIP was significantly higher than that in the offshore water $(p<0.0001)$, although its seasonal variation in the lagoon was roughly parallel to that in the offshore water. In the lagoon, DIN:DIP was usually higher during the daytime stagnant periods than in nighttime stagnant periods and flooding periods $(\mathrm{p}<0.0001)$.

Differences in DOC (Fig. 2c) and DON (Fig. 2d) between the lagoon and the offshore water were small and statistically insignificant. However, DOP (Fig. 2e) was distinctly higher in the offshore water than in the lagoon ( $\mathrm{p}<0.0001)$. In the lagoon, DOC, DON, and DOP were significantly higher during the stagnant periods than during the flooding periods ( $p \leq 0.0001)$. Differences between the day and nighttime stagnant periods were small and not significant, except for DON (higher in the day; $p=0.002$ ). DON:DOP (Table 2) and DOC:DOP (ranging from 257 to $>1000$ ) were always much higher than the Redfield ratio $(\mathrm{C}: \mathrm{N}: \mathrm{P}=106: 16: 1)$. DOC:DON (6.5 to 23.0) was also mostly higher than the Redfield ratio. Similarly to DIN:DIP, DON:DOP was distinctly higher in the lagoon than in the offshore water $(\mathrm{p}<0.0001)$ (Table 2$)$.

POC (Fig. 2f), PN (Fig. 2g), and PP (Fig. 2h) were generally higher in the lagoon than in the offshore water (significant only for PN and PP; $<<0.01$ ). In the lagoon, they were higher in the stagnant periods than in the flooding periods and also higher in the day than nighttime stagnant periods (significant only for POC and $\left.\mathrm{PN}_{i} \mathrm{p} \leq 0.0001\right)$. POC and $\mathrm{PN}$ in the lagoon were significantly higher in June 99 ( $p<0.0001$; especially during the daytime stagnant periods) than the other survey periods, while PP was higher in both December 98 and June 99 than in the other periods ( $p<0.0001)$. Similarly to DOP, chl a (data not shown) was significantly higher in the offshore water (usually 0.2 to $0.4 \mathrm{~g} \mathrm{l}^{-1}$ ) than in the lagoon (usually around $0.2 \mu \mathrm{g} \mathrm{l}^{-1}$; $\mathrm{p}<0.0001)$. However, chl a was distinctively higher during the daytime stagnant periods of June 99 $\left(\sim 0.4 \mu \mathrm{g} \mathrm{l}^{-1}\right)$, just like POC and PN. In contrast to DIN:DIP and DON:DOP, PN:PP was always lower in the lagoon than in the offshore water $(p<0.0001)$ (Table 2). Seasonal variation in PN:PP was roughly 
Table 2. N:P stoichiometry of dissolved inorganic, dissolved organic, and particulate organic matter in the lagoon and offshore waters (mean $\pm \mathrm{SE}$, sample number in parentheses)

\begin{tabular}{|c|c|c|c|c|}
\hline Season & Location and tide & $\begin{array}{l}\text { DIN:DIP } \\
(\mathrm{mol} / \mathrm{mol})\end{array}$ & $\begin{array}{c}\text { DON:DOP } \\
(\mathrm{mol} / \mathrm{mol})\end{array}$ & $\begin{array}{l}\text { PON:PP } \\
(\mathrm{mol} / \mathrm{mol})\end{array}$ \\
\hline September 1998 & $\begin{array}{l}\text { Lagoon, stagnant periods (day) } \\
\text { Lagoon, stagnant periods (night) } \\
\text { Lagoon, flooding periods } \\
\text { Offshore }\end{array}$ & $\begin{array}{l}40.3 \pm 2.1(36) \\
39.6 \pm 4.2(29) \\
24.2 \pm 2.8(24) \\
33.4 \pm 7.9(10)\end{array}$ & $\begin{array}{l}58 \pm 3(27) \\
61 \pm 14(17) \\
68 \pm 5(14) \\
47 \pm 2(10)\end{array}$ & $\begin{array}{l}22.5 \pm 1.7(14) \\
21.4 \pm 2.8(9) \\
25.6 \pm 1.8(14) \\
25.0 \pm 1.6(10)\end{array}$ \\
\hline December 1998 & $\begin{array}{l}\text { Lagoon, stagnant periods (day) } \\
\text { Lagoon, stagnant periods (night) } \\
\text { Lagoon, flooding periods } \\
\text { Offshore }\end{array}$ & $\begin{aligned} 11.4 & \pm 0.9(20) \\
11.4 & \pm 0.5(24) \\
10.1 & \pm 0.5(43) \\
9.0 & \pm 1.2(6)\end{aligned}$ & $\begin{array}{l}59 \pm 3(20) \\
54 \pm 3(12) \\
60 \pm 2(29) \\
38 \pm 1(6)\end{array}$ & $\begin{array}{l}10.9 \pm 1.0(10) \\
10.3 \pm 1.5(11) \\
10.2 \pm 0.7(22) \\
10.9 \pm 0.7(6)\end{array}$ \\
\hline March 1999 & $\begin{array}{l}\text { Lagoon, stagnant periods (day) } \\
\text { Lagoon, stagnant periods (night) } \\
\text { Lagoon, flooding periods } \\
\text { Offshore }\end{array}$ & $\begin{array}{r}22.3 \pm 2.5(30) \\
19.5 \pm 1.6(29) \\
14.6 \pm 1.4(55) \\
4.2 \pm 1.2(11)\end{array}$ & $\begin{array}{l}41 \pm 1(15) \\
42 \pm 1(15) \\
44 \pm 2(38) \\
30 \pm 1(11)\end{array}$ & $\begin{array}{c}17.4 \pm 0.3(15) \\
18.6 \pm 0.5(14) \\
17.8 \pm 0.3(37) \\
22.8 \pm 3.5(6)\end{array}$ \\
\hline June 1999 & $\begin{array}{l}\text { Lagoon, stagnant periods (day) } \\
\text { Lagoon, stagnant periods (night) } \\
\text { Lagoon, flooding periods } \\
\text { Offshore }\end{array}$ & $\begin{array}{l}66.6 \pm 6.3(29) \\
39.9 \pm 4.2(5) \\
59.7 \pm 5.1(46) \\
27.9 \pm 10.8(4)\end{array}$ & $\begin{aligned} 71 & \pm 2(16) \\
100 & \pm 15(3) \\
65 & \pm 2(37) \\
38 & \pm 1(4)\end{aligned}$ & $\begin{array}{l}22.2 \pm 0.4(15) \\
18.8 \pm 0.3(3) \\
20.7 \pm 0.5(37) \\
25.1 \pm 1.6(4)\end{array}$ \\
\hline September 1999 & $\begin{array}{l}\text { Lagoon, stagnant periods (day) } \\
\text { Lagoon, stagnant periods (night) } \\
\text { Lagoon, flooding periods } \\
\text { Offshore }\end{array}$ & $\begin{aligned} 44.6 & \pm 5.4(28) \\
38.9 & \pm 4.3(31) \\
34.1 & \pm 2.9(42) \\
8.6 & \pm 1.6(10)\end{aligned}$ & $\begin{array}{l}43 \pm 2(15) \\
46 \pm 3(16) \\
40 \pm 1(31) \\
43 \pm 1(10)\end{array}$ & $\begin{array}{l}21.8 \pm 0.4(15) \\
22.7 \pm 0.5(16) \\
23.3 \pm 0.4(31) \\
26.9 \pm 1.4(10)\end{array}$ \\
\hline
\end{tabular}

parallel to that in DIN:DIP. In the lagoon, no significant difference in PN:PP was found between stagnant and flooding periods and between daytime and nighttime stagnant periods. The POC:chl a weight ratio was higher in the lagoon (usually 190 to 480) than in the offshore water (120 to $370 ; \mathrm{p}<0.0001)$.

\section{DISCUSSION}

\section{Nitrogen metabolism of the lagoon ecosystem}

Coral reef ecosystems as a whole often export DIN to the surrounding ocean (Webb et al. 1975, Hatcher \& Hatcher 1981, Andrews \& Müller 1983, Hatcher \& Frith 1985, Charpy-Roubaud et al. 1990, Charpy et al. 1998, Rasheed et al. 2002). This net $\mathrm{N}$ export has been ascribed to exogenous $\mathrm{N}$ inputs to the reefs, especially atmospheric $\mathrm{N}_{2}$ fixation (Entsch et al. 1983, Smith 1984). However, coral reefs sometimes act as a sink of DIN when reef primary productivity is elevated in particular seasons (Hatcher \& Hatcher 1981, Johannes et al. 1983); thus, the source/sink characteristics of the whole reef ecosystem for $\mathrm{N}$ can be variable when primary productivity shows significant seasonal variations.

In the case of the Shiraho reef, concentration of DIN was always much higher in the lagoon than in offshore water (Fig. 2a), which indicated that DIN was being produced and added to seawater within the lagoon. This net production of DIN may not be ascribed to mineralization of DON or PN from the outer ocean, because DON and PN were also higher in the lagoon than in the outer ocean except in September (Fig. 2d, g); that is, concentration of $\mathrm{N}$ in seawater absolutely increased while it passed through the lagoon. As potential sources for this extra $\mathrm{N}$, biological $\mathrm{N}_{2}$ fixation (Miyajima et al. 2001, Kayanne et al. 2005b) and $\mathrm{NO}_{3}{ }^{-}$input by groundwater discharge (Umezawa et al. 2002b) have been demonstrated in the Shiraho reef. According to simple mass-balance calculations by Umezawa et al. (2002b), groundwater discharge is potentially several times more important as an $\mathrm{N}$ source to this lagoon than $\mathrm{N}_{2}$ fixation. The fact that not only $\mathrm{NO}_{3}{ }^{-}$but also $\mathrm{NH}_{4}{ }^{+}$was much higher in the lagoon than in offshore water suggests that both groundwater-derived $\mathrm{NO}_{3}{ }^{-}$and $\mathrm{NH}_{4}{ }^{+}$produced internally by mineralization of organic $\mathrm{N}$ were equally important DIN sources for the lagoon. Also, $\mathrm{NO}_{3}{ }^{-}$is not only supplied by groundwater but also internally produced by nitrification in some areas of this reef flat (T. Miyajima unpubl. data).

\section{Conservative behavior of $\mathrm{P}$ compared to $\mathrm{N}$}

Estimation of DIP exchange between coral reefs and flowing seawater has often proved to be difficult 
because variability of DIP in reef water is so small (Pilson \& Betzer 1973, Crossland \& Barnes 1983, Entsch et al. 1983, Charpy 2001). However, net DIP uptake and organic $\mathrm{P}$ release by the reef biota has been reported for the Tikehau Atoll (Charpy-Roubaud et al. 1990). Production and release of organic $\mathrm{P}$ by reef biota has also been reported by Pilson \& Betzer (1973), D'Elia (1977) and Charpy \& Charpy-Roubaud (1988). In contrast, utilization of organic $\mathrm{P}$ by reef primary producers such as macroalgae and zooxanthellae has been suggested by elevated alkaline phosphatase activities, especially under N-replete and/or P-depleted conditions (Atkinson 1987, Lapointe 1997, Schaffelke 2001, Annis $\&$ Cook 2002). Thus, the net balance of $P$ in coral reefs may be affected by the availability of $\mathrm{N}$ relative to $\mathrm{P}$ for the reef organisms.

In the Shiraho reef, concentrations of DIP and PP were higher and that of DOP was lower in the lagoon than in the offshore water (Fig. 2b,e,h). This suggests that DIP and PP were loaded to and DOP was extracted from seawater while it was passing across the lagoon. This behavior of $\mathrm{P}$ is contrasting to that observed in some other reefs such as the Tikehau Atoll (Charpy-Roubaud et al. 1990). When DIP + PP in the lagoon and the offshore waters was plotted against DOP, the data points were scattered in the vicinity of the line Total P $(\mathrm{TP}=\mathrm{DIP}+\mathrm{DOP}+\mathrm{PP})$ $=0.18 \mu \mathrm{mol} \mathrm{l}^{-1}$ (Fig. 3a); that is, $\mathrm{P}$ as a whole behaved conservatively around the Shiraho reef. Both DIP and PP were negatively correlated with DOP (Fig. 3b,c). These facts suggest that both DIP and PP were produced within the lagoon at the expense of DOP from the outer ocean. DIP and PP were not correlated with each other (Fig. 3d).

Such conservative behavior was not confirmed for $\mathrm{N}$ (Fig. 4a). Total N (TN = DIN + DON + PN) varied from 4.3 to $12.4 \mu \mathrm{mol} \mathrm{l}^{-1}$. The apparently non-conservative behavior of $\mathrm{N}$ is primarily ascribed to internal loading of groundwater $\mathrm{NO}_{3}{ }^{-}$and regenerated DIN as already discussed. In contrast to $\mathrm{P}, \mathrm{PN}$ was correlated positively to DON and DIN (Fig. 4b,d), which may suggest that internal production of DON and PN proceeded in parallel within the lagoon, probably at the expense of internally loaded DIN. Thus, the mechanism responsible for the speciation of $\mathrm{N}$ in this reef would be different from that for $\mathrm{P}$.
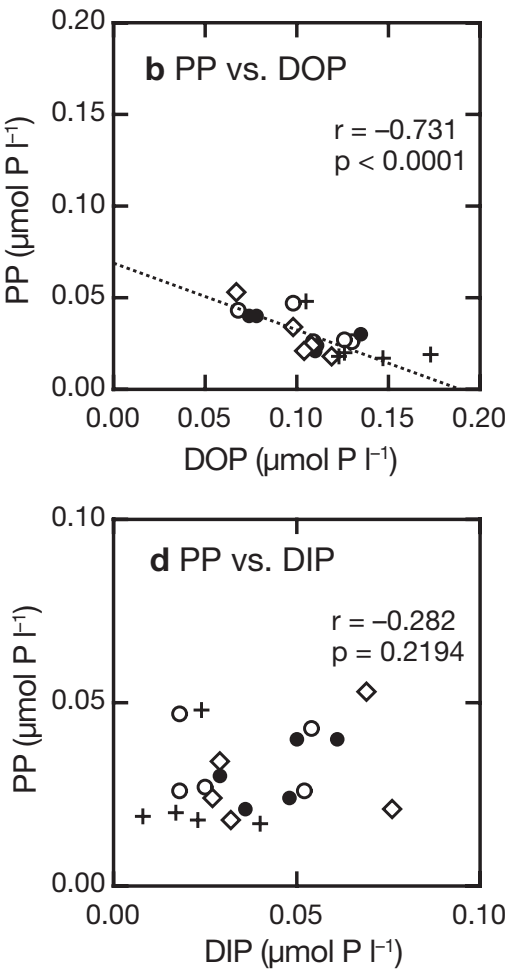

$$
\begin{array}{lll}
+ \text { Offshore } & \bullet & \text { Lagoon (stagnant, night) } \\
\diamond \text { Lagoon (flooding) } & \circ & \text { Lagoon (stagnant, day) }
\end{array}
$$

Fig. 3. Relationships of (a) DIP + PP, (b) PP, and (c) DIP to DOP, and (d) PP to DIP in the Shiraho lagoon and offshore waters. Individual concentration data (total 20 mean values for each form of P), and the mean values are plotted for every group. Broken regression lines indicate sigconstraint of constant TP (i.e. DIP + DOP + PP $=0.177 \mu \mathrm{mol} \mathrm{l}^{-1}$ )

\section{Primary production controls $\mathbf{P}$ and $\mathbf{N}$ speciation}

To examine what factors determined the speciation of $\mathrm{P}$ and $\mathrm{N}$ in this lagoon ecosystem, the effect of the primary productivity of the lagoon biota was evaluated. Gross primary production (GPP) during the daytime stagnant periods has already been published elsewhere (Hata et al. 2002, Kayanne et al. 2005a). When primary production is enhanced, DIP should be actively absorbed and PP produced by the biota, and the ratio of PP to DIP should be increased. In fact, the mean $\mathrm{PP}:(\mathrm{PP}+\mathrm{DIP})$ ratio during the daytime stagnant periods was strongly correlated with GPP (Fig. 5a). This correlation was maintained even during the nighttime stagnant periods (Fig. 5b) and the flooding periods (Fig. 5c), but disappeared in the offshore water (Fig. 5d). This relationship suggests that production of PP rather than DIP was enhanced when GPP was high. However, the partitioning of TP between (DIP + PP) and DOP was not correlated with GPP or any other measured parameters 

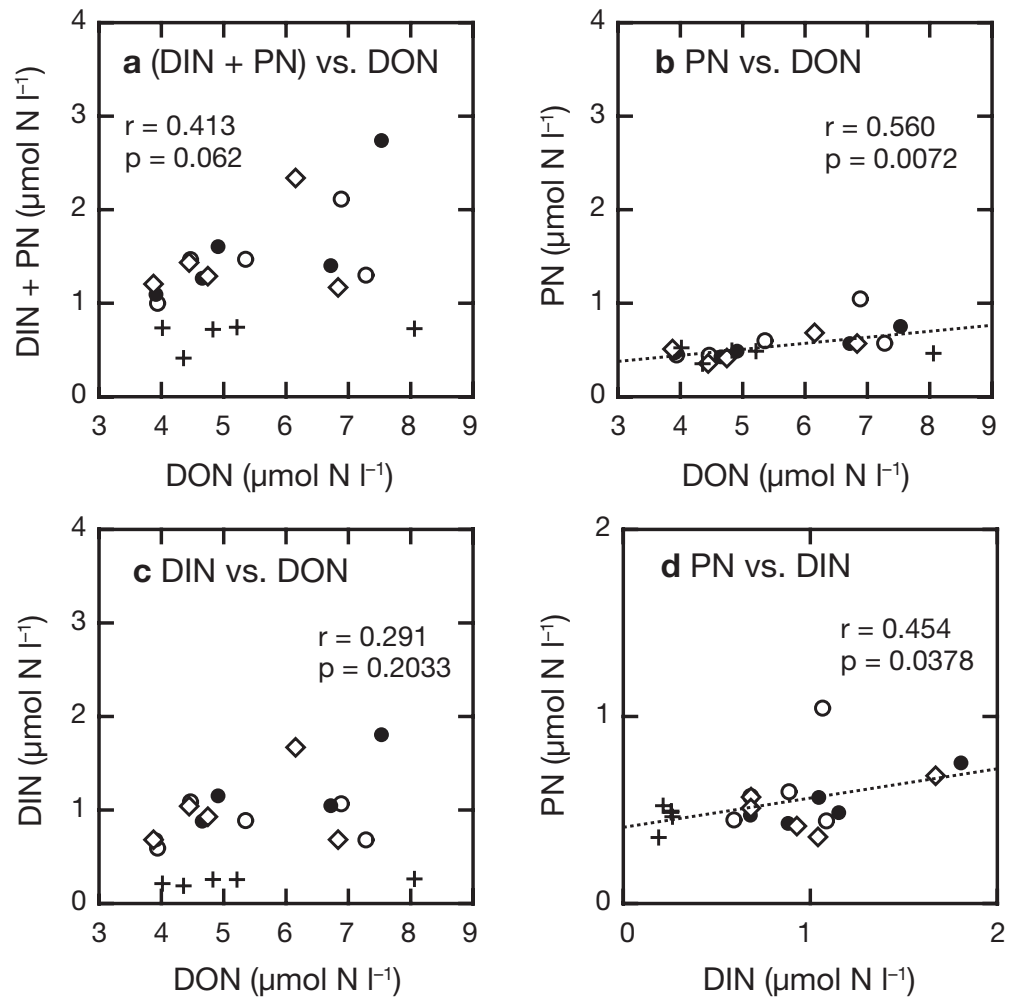

\begin{tabular}{|lll|}
\hline+ Offshore & $\bullet$ & Lagoon (stagnant, night) \\
$\diamond$ Lagoon (flooding) & $\circ$ & Lagoon (stagnant, day) \\
\hline
\end{tabular}

Fig. 4. Relationships of (a) DIN + PN, (b) PN, and (c) DIN to DON, and (d) PN to DIN in the Shiraho lagoon and offshore waters. Plotting method and symbols as in Fig. 3

such as nutrient concentrations and their ratios. Thus, what factors controlled utilization of DOP by the lagoon biota could not be specified in this study. At present, we tentatively conclude that while DOP was hydrolyzed at more or less constant rates by the lagoon biota, the fate of the hydrolyzed $\mathrm{P}$ was strongly constrained by GPP.

Partitioning of $\mathrm{N}$ into DIN, DON, and PN was not apparently correlated with GPP. However, concentration of organic $\mathrm{N}$ (= DON + PN) in the lagoon during the daytime stagnant periods was strongly correlated with GPP (Fig. 6a). This relationship suggests that organic N production in the lagoon depended primarily on primary production of the lagoon biota. The same correlation was maintained during the nighttime stagnant periods and the flooding periods, but not for the offshore samples (Fig. 6b-d), which suggests that the effect of GPP on organic $N$ production was not only instantaneous, but persisted for many hours.

\section{Interaction between N:P stoichiometry and productivity}

Mean concentrations of DON and PN during the stagnant periods were also positively correlated with the mean DIN: DIP ratio (Fig. 7a,b). This suggests that the organic $\mathrm{N}$ production by the lagoon biota was also controlled by the availability of DIN relative to DIP in the lagoon water. Thus, organic $\mathrm{N}$ was produced by the lagoon biota and eventually exported to the outer ocean when both GPP and DIN:DIP were high. Chl a was also correlated strongly with DIN:DIP (Fig. 7c) and PN (data not shown), which suggested that release of zooxanthellae by hermatypic

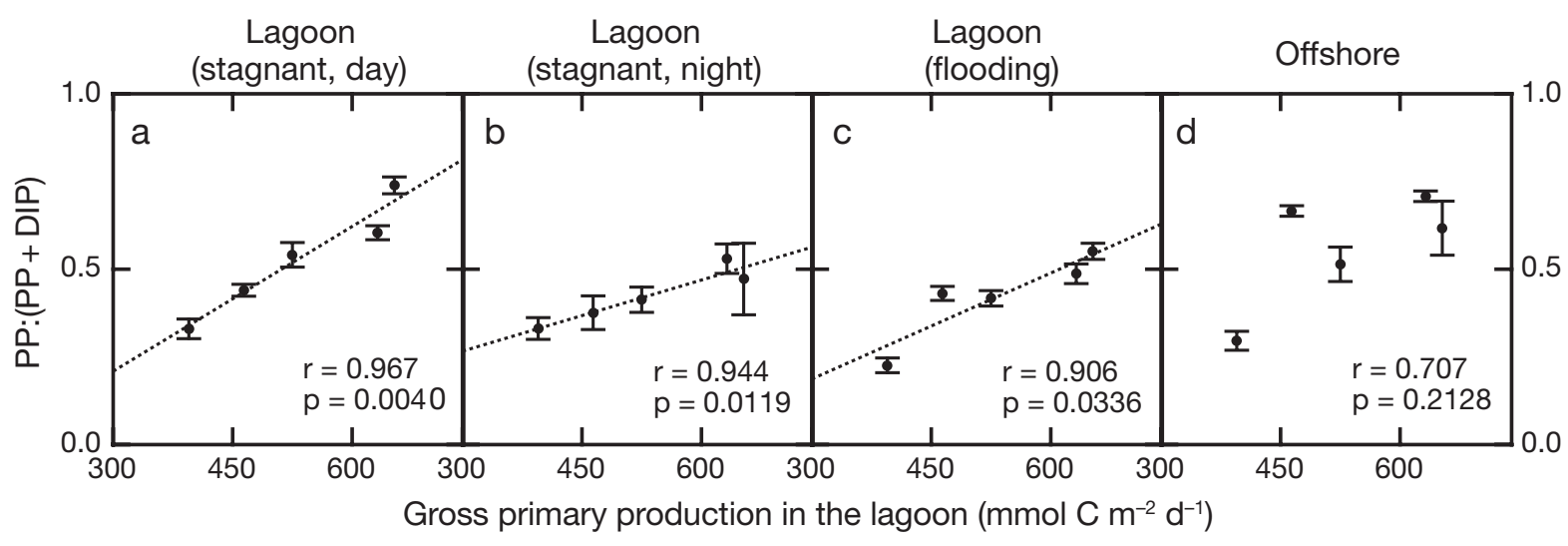

Fig. 5. Relationships of the ratio PP: $(P P+D I P)$ in $(a-c)$ the lagoon and $(d)$ offshore waters to gross primary production $(G P P)$ in the lagoon. Mean ratio \pm SE (error bar) for each of the 5 survey periods are plotted. GPP was estimated for individual daytime stagnant periods in the lagoon and averaged for each survey period ( $\mathrm{n}=3$ or 4 ; see Hata et al. [2002] for details). Linear regression lines are shown for significant correlations $(p<0.05)$ 


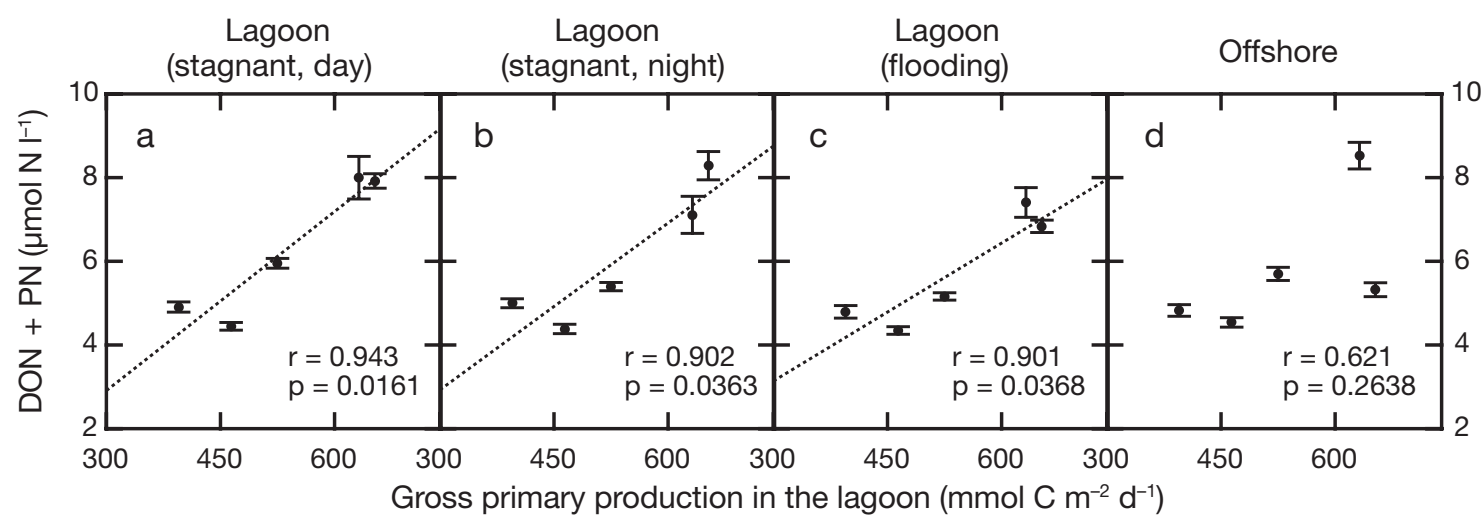

Fig. 6. Relationships of organic N (DON $+\mathrm{PN})$ in $(\mathrm{a}-\mathrm{c})$ the lagoon and (d) offshore waters to gross primary production $(\mathrm{GPP})$ in the lagoon. Mean concentration \pm SE (error bar) for each of the 5 survey periods are plotted. GPP data as in Fig. 5 . Linear regression lines are shown for significant correlations $(p<0.05)$

corals might have been responsible for the observed increase of PN with increasing GPP.

From these results, the following scenario is proposed for the speciation of $\mathrm{N}$ and $\mathrm{P}$ within this lagoon. The lagoon biota produced PP and DIP at the expense of DOP supplied from the outer ocean, and the fraction of PP increased and that of DIP decreased as GPP increased in warmer seasons. As the lagoon water was usually rich in $\mathrm{N}$ relative to $\mathrm{P}$, the depletion of DIP led to a very high DIN:DIP ratio in summer, which in turn disturbed the metabolic balance between primary production and biomass growth of the lagoon biota, resulting in export production of DON and PN.

Thus, the behavior of $\mathrm{P}$ within this lagoon ecosystem contrasts that of $N$, especially with respect to the role of the dissolved organic phase in element exchange across the ecosystem boundary. This contrasting behavior of $\mathrm{P}$ to $\mathrm{N}$ is likely related to potential $\mathrm{P}$ limitation that prevailed over the Shiraho reef. However, the relationship between $\mathrm{N}: \mathrm{P}$ stoichiometry in ambient water and limiting nutrients for the biota is not simple, when the $\mathrm{N}: \mathrm{P}$ ratio of major primary producers is highly variable (D'Elia \& Wiebe 1990). In fact, primary producers of coral reefs, such as macroalgae and seagrasses, have highly variable N:P ratios, often much higher than the Redfield ratio (Atkinson \& Smith 1983). Also, tissue N:P ratios of scleractinian corals in the Shiraho reef are generally high, ranging from 22 to 33 (S. Harii unpubl. data). Furthermore, availability of DON and DOP for reef primary producers is also controversial. Since the major part of DOP is presumably phosphate esters that are readily cleaved by alkaline phosphatases (AP), it may be assumed that DOP is mostly available for primary producers possessing AP, such as macroalgae and zooxanthellae. However, DON generally has a more complex chemical structure and is on average less degradable than DOP (Hopkinson et al. 2002). Consequently, the N:P ratio of available fractions of DON and DOP may be considerably lower than the measured DON:DOP. Thus, whether primary production in the Shiraho reef is actually limited by $\mathrm{P}$ or $\mathrm{N}$ and to what degree DON and DOP from
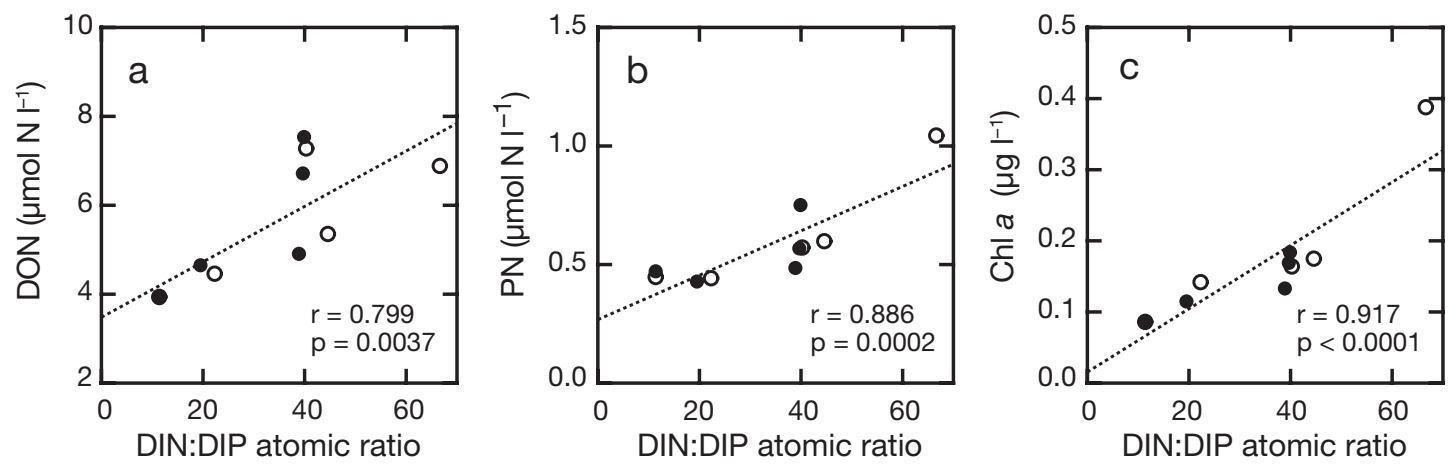

$$
\text { ○ Lagoon (stagnant, day) • Lagoon (stagnant, night) }
$$

Fig. 7. Relationships of DON, PN, and chl a to DIN:DIP ratio in the lagoon water during the stagnant periods. Plotting method and symbols are the same as in Fig. 3. Linear regression lines are also shown with $r$ and $p$ values 
the offshore water are available for the reef primary producers are problems left to be resolved in the future.

\section{Exchange fluxes of $C, N$, and $P$ at the ecosystem boundary}

Finally, exchange fluxes of $\mathrm{C}, \mathrm{N}$, and $\mathrm{P}$ between the lagoon ecosystem and the adjacent outer ocean were calculated using average nutrient concentrations in respective tidal phases of the lagoon and in the offshore water shown in Fig. 2. To this aim, some assumptions were made about the hydrodynamics of this lagoon. First, the lagoon water chemistry was assumed to be homogeneous and represented by the data collected at our sampling station. Water turnover time of the lagoon during the flooding periods has been estimated to be ca. $3 \mathrm{~h}$ (H. Yamano unpubl. data). As the duration of a single flooding period was ca. $6 \mathrm{~h}$ at spring tide, it was assumed that the lagoon water was replaced twice during each flooding period. It was further assumed that at the first turnover in a given flooding period, lagoon water having average nutrient concentrations for the stagnant periods of a given month was replaced with seawater having average nutrient concentrations for the offshore water of the same month, and at the second turnover, lagoon water with average nutrient concentrations for the flooding periods of the same month was replaced with the offshore water. Finally, it was assumed that $\mathrm{C}, \mathrm{N}$, and $\mathrm{P}$ in the lagoon water replaced by tidal exchange were exported to the outer ocean, while those in the entering offshore water were imported to the lagoon. Daily amounts of $\mathrm{C}, \mathrm{N}$, and $\mathrm{P}$ export and import were thus calculated for unit bottom area of the lagoon from concentration data in Fig. 2, assuming that average water depths of the lagoon during the stagnant and flooding periods were 1.5 and $2.0 \mathrm{~m}$, respectively, and that there were 1 daytime stagnant, 1 nighttime stagnant, and 2 flooding periods per day. Daily exchange rates were at first estimated for respective study months, and then averaged for a whole year (i.e. December 98, March 99, June 99, and September 99) to obtain annual average budgets (Table 3 ).

Export flux from the lagoon to the outer ocean exceeded import flux for both DOC and $\mathrm{POC}$, resulting in an annual average export production of $18 \mathrm{mmol} \mathrm{C} \mathrm{m}^{-2} \mathrm{~d}^{-1}$. The lagoon ecosystem as a whole was a net source of organic $\mathrm{C}$ to the surrounding ocean, and this conclusion is consistent with previous studies on primary production of this reef (Kayanne et al. 1995, 2005a, Hata et al. 2002). However, the net export of organic $\mathrm{C}$ was only a small fraction $(<5 \%)$ of the gross import and export fluxes of organic C (Table 3 ). This suggests that organic C imported by inflowing oceanic water to the lagoon was flushed back to the outer ocean with little interaction with the lagoon biota, and that organic $\mathrm{C}$ production within the lagoon could have only a minor impact on the carbon cycle in the outer ocean.

Table 3. Budgets of organic carbon, total nitrogen, and phosphorus in the lagoon of Shiraho reef. Exchange amounts are expressed by moles per unit bottom area of the lagoon $\left(\mathrm{mmol} \mathrm{m}^{-2} \mathrm{~d}^{-1}\right)$, with positive values indicating net gains by the lagoon. Values in boldface highlight the total balance

\begin{tabular}{|c|c|c|c|}
\hline Elements & $\begin{array}{l}\text { Import to } \\
\text { the lagoon }\end{array}$ & $\begin{array}{l}\text { Export from } \\
\text { the lagoon }\end{array}$ & $\begin{array}{c}\text { Balance } \\
\left(\mathrm{mmol} \mathrm{m}^{-2} \mathrm{~d}^{-1}\right)\end{array}$ \\
\hline \multicolumn{4}{|l|}{ Carbon } \\
\hline \multicolumn{4}{|c|}{ Exchange with the outer ocean ${ }^{a}$} \\
\hline Dissolved organic & $389 \pm 46$ & $-404 \pm 29$ & $-15 \pm 57$ \\
\hline Particulate organic & $28 \pm 4$ & $-30 \pm 8$ & $-2 \pm 6$ \\
\hline Total organic & $416 \pm 44$ & $-434 \pm 32$ & $-18 \pm 59$ \\
\hline \multicolumn{4}{|c|}{ During the bleaching period (September 1998) ${ }^{\mathrm{b}}$} \\
\hline Dissolved organic & & & $-30 \sim-36$ \\
\hline Particulate organic & & & $-5 \sim-7$ \\
\hline Total organic & & & $-35 \sim-43$ \\
\hline \multicolumn{4}{|l|}{ Nitrogen } \\
\hline \multicolumn{4}{|c|}{ Exchange with the outer ocean ${ }^{a}$} \\
\hline Dissolved inorganic & $1.6 \pm 0.2$ & $-7.4 \pm 2.6$ & $-5.8 \pm 2.5$ \\
\hline Dissolved organic & $32.3 \pm 3.7$ & $-34.8 \pm 8.1$ & $-2.6 \pm 6.7$ \\
\hline Particulate & $3.3 \pm 0.5$ & $-3.7 \pm 1.2$ & $-0.5 \pm 1.0$ \\
\hline Subtotal & $37.1 \pm 4.0$ & $-45.9 \pm 11.8$ & $-8.9 \pm 10.1$ \\
\hline \multicolumn{4}{|l|}{ Other external input } \\
\hline Groundwater nitrate $^{\mathrm{c}}$ & $1.1 \sim 1.5$ & & $1.1 \sim 1.5$ \\
\hline Nitrogen fixation $^{\mathrm{d}}$ & $0.13 \sim 0.24$ & & $0.13 \sim 0.24$ \\
\hline Atmospheric deposition ${ }^{\mathrm{e}}$ & $<0.1$ & & $<0.1$ \\
\hline \multicolumn{4}{|l|}{ Other output } \\
\hline Denitrification $^{\mathrm{d}}$ & & $-0.04 \sim-0.28$ & $-0.04 \sim-0.28$ \\
\hline Total & & & $-7.6(-18 \sim+3)$ \\
\hline \multicolumn{4}{|l|}{ Phosphorus } \\
\hline \multicolumn{4}{|c|}{ Exchange with the outer ocean ${ }^{a}$} \\
\hline Dissolved inorganic & $0.18 \pm 0.07$ & $-0.34 \pm 0.13$ & $-0.15 \pm 0.10$ \\
\hline Dissolved organic & $0.88 \pm 0.12$ & $-0.68 \pm 0.15$ & $0.20 \pm 0.11$ \\
\hline Particulate & $0.18 \pm 0.10$ & $-0.23 \pm 0.09$ & $-0.05 \pm 0.06$ \\
\hline Total & $1.24 \pm 0.13$ & $-1.24 \pm 0.09$ & $0.00 \pm 0.05$ \\
\hline \multicolumn{4}{|c|}{$\begin{array}{l}\text { aAverage and SD for } 4 \text { seasons (December 1998, March, June, September } \\
\text { 1999). Data for September } 1998 \text { were omitted because significant coral } \\
\text { bleaching occurred in that month. See text for calculation method } \\
\text { b According to Hata et al. (2002) } \\
\text { cAccording to Umezawa et al. (2002b). As DIN:DIP ratio in groundwater } \\
\text { is around 1000, groundwater is a negligible source for P budget } \\
\text { dAccording to Miyajima et al. (2001) } \\
\text { eEstimated by Umezawa et al. (2002b) }\end{array}$} \\
\hline
\end{tabular}


Export fluxes of DIN, DON, and PN from the lagoon were larger than corresponding import fluxes, making the $\mathrm{N}$ balance of the lagoon a net loss of $8.9 \mathrm{mmol} \mathrm{m}^{-2}$ $\mathrm{d}^{-1}$. More than half of this loss was ascribed to net export of DIN (5.8 $\left.\mathrm{mmol} \mathrm{m}^{-2} \mathrm{~d}^{-1}\right)$, about three-fourths of which were that of $\mathrm{NO}_{3}{ }^{-}\left(4.1 \mathrm{mmol} \mathrm{m}^{-2} \mathrm{~d}^{-1}\right)$. These figures are distinctly higher than the net $\mathrm{N}$ production at the Tikehau Atoll $\left(0.6 \mathrm{mmol} \mathrm{m} \mathrm{m}^{-1}\right.$; CharpyRoubaud et al. 1990) and eddy-diffusional mixing loss of DIN from One Tree Reef lagoon (1.0 to $1.4 \mathrm{mmol} \mathrm{m}^{-2}$ $\mathrm{d}^{-1}$, based on lagoon-center measurements; Hatcher \& Frith 1985), and again indicating relatively N-rich conditions in the Shiraho reef. Mioche \& Cuet (1999) compared nutrient fluxes between an intact and a degraded reef site at Reunion Island fringing reef, and detected statistically significant export fluxes of DIN (6.2 and $0.6 \mathrm{mmol} \mathrm{m}^{-2} \mathrm{~d}^{-1}$ for $\mathrm{NO}_{3}{ }^{-}$and $\mathrm{NO}_{2}{ }^{-}$, respectively) only in the degraded site where macroalgal overgrowth occurred. Webb et al. (1975) determined DIN, DON, and PN fluxes on benthic algae-dominated pavements of Enewetak Atoll. The measured DIN flux was highly variable, being net import flux in some cases and net efflux of similar magnitude to that of Shiraho lagoon in other cases; however, the measured flux of total $\mathrm{N}$ was generally net export ranging from 2 to $33 \mathrm{mmol} \mathrm{m}^{-2} \mathrm{~d}^{-1}$. Andrews \& Müller (1983) measured regenerative nutrient flux within a single patch reef of Davies reef lagoon, and reported an export flux of $\mathrm{NO}_{3}{ }^{-}$of ca. $17 \mathrm{mmol} \mathrm{m}^{-2} \mathrm{~d}^{-1}$, about 4 times higher than average $\mathrm{NO}_{3}{ }^{-}$export from Shiraho lagoon. Thus, coral reef ecosystems can export significant amounts of $\mathrm{N}$ to the surrounding ocean when benthic algal biomass (presumably associated with $\mathrm{N}_{2}$-fixing microbes) increases to some extent and/or when decomposition and regeneration are activated due to accumulation of detrital organic matter. The high algal production and elevated regeneration may be characteristics common to high-latitude coral reefs (Crossland et al. 1984), including our study site.

This net $\mathrm{N}$ loss could be partially compensated by some external sources other than oceanic inflow, e.g. groundwater nitrate input and biological $\mathrm{N}_{2}$ fixation (up to $2 \mathrm{mmol} \mathrm{m}^{-2} \mathrm{~d}^{-1}$; Umezawa et al. 2002b). However, a relatively large fraction of the net $\mathrm{N}$ loss (ca. $7 \mathrm{mmol} \mathrm{m} \mathrm{m}^{-2} \mathrm{~d}^{-1}$ ) still remained to be compensated. There may be some unknown external $\mathrm{N}$ sources to the lagoon. It is also possible that reported estimates for groundwater $\mathrm{N}$ input, $\mathrm{N}_{2}$ fixation, and atmospheric $\mathrm{N}$ deposition are underestimates. In addition, there was a large uncertainty in the estimate of DON export from the lagoon (Table 3), which in turn was derived from relatively large seasonal variability in DON concentration in the lagoon water (Fig. 2). Thus, to make the $\mathrm{N}$ budget estimation more reliable, it is desirable to obtain more detailed and precise data for
DON and to understand the mechanisms that control the dynamics of DON within the lagoon ecosystem. In contrast to organic $\mathrm{C}$, the fraction of net export to gross import or export fluxes of $\mathrm{N}$ was relatively large, ca. $20 \%$. Especially, net export of DIN was more than half of gross export flux and several times larger than gross import flux. This figure illustrates the highly dissipative nature of $\mathrm{N}$ cycling in this lagoon ecosystem.

Export fluxes of DIP and PP from the lagoon exceeded their import fluxes, while import flux was larger than export flux for DOP. However, the total budget for $\mathrm{P}$ was just balanced (Table 3). This fact suggests again that this lagoon ecosystem is rather conservative for P. Because there is apparently no significant external source of $\mathrm{P}$ other than oceanic inflow, this conservative nature of $\mathrm{P}$ exchange of this lagoon is not surprising, nor is it necessarily related to the relatively $\mathrm{N}$-rich conditions that prevail over this reef system. In fact, similar conclusions of a balanced $\mathrm{P}$ budget have also been drawn for Enewetak and Tikehau Atolls (Pilson \& Betzer 1973, Charpy-Roubaud et al. 1990). In these 2 atolls, however, DIP was imported to and organic $\mathrm{P}$ was exported from the biota. The relatively large net gain of DOP $\left(0.20 \mathrm{mmol} \mathrm{m}^{-2} \mathrm{~d}^{-1}\right)$ and net export of DIP in Shiraho lagoon would be a result of the high DIN:DIP ratio in the lagoon water, as discussed in earlier sections. The same fact also suggests that the coral reef ecosystem may not be as capable of producing DOP as it does DOC and DON. These points should be examined in the future by a comparative biogeochemical study of different coastal ecosystems.

In conclusion, we showed that the Shiraho reef ecosystem exports a significant amount of bioavailable $\mathrm{N}$ to the outer ocean and potentially influences the $\mathrm{N}$ cycle in the adjacent coastal ocean. The influence of this reef on the oceanic $\mathrm{C}$ and $\mathrm{P}$ cycles is apparently insignificant. The export $\mathrm{N}$ flux is related to high organic-N production and regeneration activities within the lagoon that in turn are supported by land-derived DIN input and microbiological $\mathrm{N}_{2}$ fixation. The high organic production as well as $\mathrm{N}$ export may be characteristic of high-latitude coral reefs such as the Shiraho reef.

Acknowledgements. This study was conducted as a part of a multidisciplinary monitoring project for coral reef metabolism of the 'CREST' program supported by the Japan Science and Technology Agency from 1996 to 2001. Laboratory facilities on Ishigaki Island were kindly offered by the Japan SeaFarming Association, Yaeyama Station. Field surveys were assisted by graduate students of the Department of Earth and Planetary Science of The University of Tokyo, members of the Shiraho Fishermen's Cooperative, and technical staff of Kimoto Electric Co., Ltd., and Fuyo Ocean Development \& Engineering Co., Ltd. 


\section{LITERATURE CITED}

Andrews JC, Müller H (1983) Space-time variability of nutrients in a lagoonal patch reef. Limnol Oceanogr 28: 215-227

Annis ER, Cook CB (2002) Alkaline phosphatase activity in symbiotic dinoflagellates (zooxanthellae) as a biological indicator of environmental phosphate exposure. Mar Ecol Prog Ser 245:11-20

Anthony KRN (2000) Enhanced particle-feeding capacity of corals on turbid reefs (Great Barrier Reef, Australia). Coral Reefs 19:59-67

Atkinson MJ (1987) Alkaline phosphatase activity of coral reef benthos. Coral Reefs 6:59-62

Atkinson MJ, Falter JL (2003) Coral reefs. In: Black KD, Shimmield GB (eds) Biogeochemistry of marine systems. Blackwell Publishing, Oxford, p 40-64

Atkinson MJ, Smith SV (1983) C:N:P ratios of benthic marine plants. Limnol Oceanogr 28:568-574

Cembella AD, Antia NJ, Taylor FJR (1986) The determination of total phosphorus in seawater by nitrate oxidation of the organic component. Water Res 20:1197-1199

Charpy L (2001) Phosphorus supply for atoll biological productivity. Coral Reefs 20:357-360

Charpy L, Charpy-Roubaud CJ (1988) Phosphorus budget in an atoll lagoon. Proc 6th Int Coral Reef Symp 2:547-550

Charpy L, Charpy-Roubaud C, Buat P (1998). Excess primary production, calcification and nutrient fluxes of a patch reef (Tikehau atoll, French Polynesia). Mar Ecol Prog Ser 173: 139-147

Charpy-Roubaud CJ, Charpy L, Cremoux JL (1990) Nutrient budget of the lagoonal waters in an open central South Pacific atoll (Tikehau, Tuamotu, French Polynesia). Mar Biol 107:67-73

Crossland CJ, Barnes DJ (1983) Dissolved nutrients and organic particles in water flowing over coral reefs at Lizard Island. Aust J Mar Freshw Res 34:835-844

Crossland CJ, Hatcher BG, Atkinson MJ, Smith SV (1984) Dissolved nutrients of a high-latitude coral reef, Houtman Abrolhos Islands, Western Australia. Mar Ecol Prog Ser 14:159-163

D'Elia CF (1977) The uptake and release of dissolved phosphorus by reef corals. Limnol Oceanogr 22:301-315

D'Elia CF (1988) The cycling of essential elements in coral reefs. In: Pomeroy LR, Alberts JJ (eds) Concepts of ecosystem ecology. Springer, New York, NY, p 195-230

D'Elia CF, Wiebe WJ (1990) Biogeochemical nutrient cycles in coral-reef ecosystems. In: Dubinsky Z (ed) Coral reefs. Elsevier Science, Amsterdam, p 49-74

D'Elia CF, Webb KL, Porter JW (1981) Nitrate-rich groundwater inputs to Discovery Bay, Jamaica: A significant source of $N$ to local coral reefs? Bull Mar Sci 31:903-910

Entsch B, Boto KG, Sim RG, Wellington JT (1983) Phosphorus and nitrogen in coral reef sediments. Limnol Oceanogr 28: $465-476$

Grasshoff K, Kremling K, Ehrhardt M (1999) Method of seawater analysis. Wiley-VCH, Weinheim

Hamner WM, Jones MS, Carleton JH, Hauri IR, Williams DMB (1988) Zooplankton, planktivorous fish, and water currents on a windward reef face: Great Barrier Reef, Australia. Bull Mar Sci 43:459-479

Hata H, Kudo S, Yamano H, Kurano N, Kayanne H (2002) Organic carbon flux in Shiraho coral reef (Ishigaki Island, Japan). Mar Ecol Prog Ser 232:129-140

Hatcher AI, Frith CA (1985) The control of nitrate and ammonium concentrations in a coral reef lagoon. Coral Reefs 4: $101-110$
Hatcher AI, Hatcher BG (1981) Seasonal and spatial variation in dissolved inorganic nitrogen in One Tree Reef lagoon. Proc 4th Int Coral Reef Symp 1:420-425

Hopkinson Jr CS, Vallino JJ, Nolin A (2002) Decomposition of dissolved organic matter from the continental margin. Deep-Sea Res 49:4461-4478

Hung JJ, Chen CH, Gong GC, Sheu DD, Shiah FK (2003) Distribution, stoichiometric patterns and cross-shelf exports of dissolved organic matter in the East China Sea. DeepSea Res II 50:1127-1145

Johannes RE, Wiebe WJ, Crossland CJ (1983) Three patterns of nutrient flux in a coral reef community. Mar Ecol Prog Ser 12:131-136

Kayanne H, Suzuki A, Saito H (1995) Diurnal changes in the partial pressure of carbon dioxide in coral reef water. Science 269:214-216

Kayanne H, Hata H, Kudo S, Yamano H and 6 others (2005a) Seasonal and bleaching-induced changes in coral reef metabolism and $\mathrm{CO}_{2}$ flux. Global Biogeochem Cycles 19: GB3015, doi: 10.1029/2004GB002400

Kayanne H, Hirota M, Yamamuro M, Koike I (2005b) Nitrogen fixation of filamentous cyanobacteria in a coral reef measured using three different methods. Coral Reefs 24: 197-200

Lapointe BE (1997) Nutrient thresholds for bottom-up control of macroalgal blooms on coral reefs in Jamaica and southeast Florida. Limnol Oceanogr 42:1119-1131

Larkum AWD, Kennedy IR, Muller WJ (1988) Nitrogen fixation on a coral reef. Mar Biol 98:143-155

Leichter JL, Wing SR, Miller SL, Denny MW (1996) Pulsed delivery of subthermocline water to Conch Reef (Florida Keys) by internal tidal bores. Limnol Oceanogr 41:1490-1501

Mioche D, Cuet P (1999) Métabolisme du carbone, des carbonates et des sels nutritifs en saison chaude, sur un récif frangeant soumis à une pression anthropique (île de la Réunion, océan Indien). C R Acad Sci Ser II A Sci Terre Planetes 329:53-59

Miyajima T, Suzumura M, Umezawa Y, Koike I (2001) Microbiological nitrogen transformation in carbonate sediments of a coral-reef lagoon and associated seagrass beds. Mar Ecol Prog Ser 217:273-286

Miyajima T, Tanaka Y, Koike I, Yamano H, Kayanne H (2007) Evaluation of spatial correlation between nutrient exchange rates and benthic biota in a reef-flat ecosystem by GIS-assisted flow-tracking. J Oceanogr 63:643-659

Moore JK, Doney SC, Glover DM, Fung IY (2002) Iron cycling and nutrient limitation patterns in surface waters of the World Ocean. Deep-Sea Res II 49:463-507

Pilson MEQ, Betzer SB (1973) Phosphorus flux across a coral reef. Ecology 54:581-588

Rasheed M, Badran MI, Richter C, Huettel M (2002) Effect of reef framework and bottom sediment on nutrient enrichment in a coral reef of the Gulf of Aqaba, Red Sea. Mar Ecol Prog Ser 239:277-285

Rosenfield M, Bresler V, Abelson A (1999) Sediment as a possible source of food for corals. Ecol Lett 2:345-348

Rougerie F, Fagerstrom JA, Andrie C (1992) Geothermal endo-upwelling: a solution to the reef nutrient paradox? Cont Shelf Res 12:785-798

Schaffelke B (2001) Surface alkaline phosphatase activities of macroalgae on coral reefs of the central Great Barrier Reef, Australia. Coral Reefs 19:310-317

Smith SV (1984) Phosphorus versus nitrogen limitation in the marine environment. Limnol Oceanogr 29:1149-1160

Solórzano L, Sharp JH (1980) Determination of total dissolved phosphorus and particulate phosphorus in natural waters. Limnol Oceanogr 25:754-758 
Suzuki R, Ishimaru T (1990) An improved method for the determination of phytoplankton chlorophyll using $\mathrm{N}, \mathrm{N}$ dimethylformamide. J Oceanogr 46:190-194

Tanaka Y, Miyajima T, Koike I, Hayashibara T, Ogawa H (2006) Translocation and conservation of organic nitrogen within the coral-zooxanthella symbiotic system of Acropora pulchra, as demonstrated by dual isotope-labeling techniques. J Exp Mar Biol Ecol 336:110-119

Tomascik T, Sander F (1985) Effects of eutrophication on reefbuilding corals: I. Growth rate of the reef-building coral Montastrea annularis. Mar Biol 87:143-155

Umezawa Y (1998) Nutrient input from terrestrial groundwater into two coral reefs: Shiraho and Kabira Reefs, the Ryukyu Islands, Southwest Japan. BSc thesis, The University of Tokyo (in Japanese with English summary)

Umezawa Y, Miyajima T, Yamamuro M, Kayanne H, Koike I (2002a) Fine-scale mapping of land-derived nitrogen in coral reefs by $\delta^{15} \mathrm{~N}$ in macroalgae. Limnol Oceanogr 47 : 1405-1416

Editorial responsibility: Otto Kinne (Editor-in-Chief), Oldendorf/Luhe, Germany
Umezawa Y, Miyajima T, Kayanne H, Koike I (2002b) Significance of groundwater nitrogen discharge into coral reefs at Ishigaki Island, southwest of Japan. Coral Reefs 21: 346-356

Webb KL, DuPaul WD, Wiebe W, Sottile W, Johannes RE (1975) Enewetak (Eniwetok) Atoll: aspects of the nitrogen cycle on a coral reef. Limnol Oceanogr 20:198-210

Wiebe WJ, Johannes RE, Webb KL (1975) Nitrogen fixation in a coral reef community. Science 188:257-259

Wilkinson CR, Williams MB, Sammarco PW, Hogg RW, Trott LA (1984) Rates of nitrogen fixation on coral reefs across the continental shelf of the central Great Barrier Reef. Mar Biol 80:255-262

Wolanski E, Drew E, Abel KM, O'Brien J (1988) Tidal jets, nutrient upwelling and their influence on the productivity of the alga Halimeda in the Ribbon Reefs, Great Barrier Reef. Estuar Coast Shelf Sci 26:169-201

Wong GTF, Gong GC, Liu KK, Pai SC (1998) 'Excess nitrate' in the East China Sea. Estuar Coast Shelf Sci 46:411-418

Submitted: July 24, 2006; Accepted: January 2, 2007

Proofs received from author(s): June 23, 2007 